\title{
ARTIGO
}

dO https://doi.org/10.22481/praxisedu.v15i36.5893

\section{THE CONJUNCTION ADAPUN IN THE INDONESIAN LANGUAGE}

\author{
LA CONJUNCIÓN ADAPTADA EN EL IDIOMA INDONESIO
}

A CONJUNÇÃO ADAPTUN NO IDIOMA INDONÉSIO

Umi Kulsum

Padjadjaran University, Sumedang, West Java - Indonesia

Cece Sobarna

Padjadjaran University, Sumedang, West Java - Indonesia

Tajudin Nur

Padjadjaran University, Sumedang, West Java - Indonesia

Wagiati

Padjadjaran University, Sumedang, West Java - Indonesia

\begin{abstract}
This study aimed to describe the function and the meaning of adapun in Indonesia and also the appropriate sentence structure of adapun. This writing uses a qualitative method with descriptive data and extended examples, based on the empirical facts or phenomena that are relevant to the lives of the users, and discussion. Data collection is done by note taking (library research) - gathering research data. Data sources are derived from print media, scientific writing, and textbooks. We conclude that the function of adapun has a close linkage with the above-mentioned conjunction. The meanings of adapun were: (1) adding information and explaining the previous sentence, (2) usher in the parsing, (3) stating something different but in the same domain, and (4) stating further information. Most of the predicates that contain adapun include the word adalah ("there is/are"), so in large measure, the context is regarded as stating a definition. In general, the sentence pattern that contains adapun is a simple sentence with the subject that is generally in the form of long phrases and the pattern is S-P-O-A.
\end{abstract}

Keywords: Adapun; Conjuction; Indonesian

Resumen: Este estudio tuvo como objetivo describir la función y el significado de adaptación en Indonesia y también la estructura de oración apropiada de adaptación. Este escrito utiliza un método cualitativo con datos descriptivos y ejemplos extendidos, basados en hechos empíricos o fenómenos que son relevantes para la vida de los usuarios y la discusión. La recopilación de datos se realiza mediante la toma de notas (investigación de la biblioteca): recopilación de datos de investigación. Las fuentes de datos se derivan de los medios 
impresos, la escritura científica y los libros de texto. Llegamos a la conclusión de que la función de adaptación tiene una estrecha vinculación con la conjunción mencionada anteriormente. Los significados de adaptación fueron: (1) agregar información y explicar la oración anterior, (2) marcar el comienzo del análisis, (3) indicar algo diferente pero en el mismo dominio, y (4) indicar más información. La mayoría de los predicados que contienen adaptaun incluyen la palabra adalah ("hay / son"), por lo que, en gran medida, se considera que el contexto establece una definición. En general, el patrón de oración que contiene una adaptación es una oración simple con el sujeto que generalmente tiene la forma de frases largas y el patrón es S-P-O-A.

Palabras clave: Adaptación; Conjunción; Indonesio

Resumo: Este estudo teve como objetivo descrever a função e o significado do adapun na Indonésia e também a estrutura de sentenças apropriada do adapun. Esta redação utiliza um método qualitativo com dados descritivos e exemplos estendidos, com base em fatos ou fenômenos empíricos relevantes para a vida dos usuários e discussão. A coleta de dados é feita por anotações (pesquisa em biblioteca) - coleta de dados de pesquisa. As fontes de dados são derivadas de mídia impressa, redação científica e livros didáticos. Concluímos que a função de adapun tem uma estreita ligação com a conjunção mencionada acima. Os significados de adaptun foram: (1) adicionar informações e explicar a frase anterior, (2) inaugurar a análise, (3) declarar algo diferente, mas no mesmo domínio, e (4) declarar informações adicionais. A maioria dos predicados que contêm adaptun inclui a palavra adalah ("existe / existe"); portanto, em grande medida, o contexto é considerado como afirmando uma definição. Em geral, o padrão de sentença que contém adapun é uma sentença simples com o assunto geralmente em forma de frases longas e o padrão é S-P-O-A.

Palavras-chave: Adaptação; Conjunção; Indonésio

\section{Introduction}

There has been much research and assessment about aspects of the Indonesian language, including verbs. But this does not mean that all aspects of Indonesian have been completely discussed. One of the incomplete aspects is the inter-sentence conjunction. Unlike the inter-sentence/inter-clause conjunction that is widely discussed in grammar, including the Standard Grammar of Indonesian Language (Alwi, 2003), the inter-sentence conjunction has escaped the attention of grammarians. The grammar standard as a reference of Indonesian grammar is the inter-sentence conjunction with the coordinative conjunction, correlative conjunction, and subordinative conjunction. This conjunction is widely discussed in the separate chapter, namely chapter X, "The Relation among Clauses." Meanwhile, the relation among sentences is not discussed. 
One of the inter-sentence conjunctions that have unique characteristic is adapun. In composite writing it is closer to the characteristics of a particle that means matter, about, or in the matter of, for example in the sentence "As for me, I was told by him to ask for help." Meanwhile, adapun (separated writing) functions as a verb and means "although there is/are," for example, Ada pun, "It is not certain he wants to give." Ada pun becomes more interesting in the linguistics of Indonesian because this word can become a conjunction between clauses. In the standard grammar of Indonesian, the and/or conjunction between paragraphs is called an opening discourse adverb; in the Indonesian Dictionary (Ministry of Education, 2005) it is stated as a particle. Chaer (2009), Putrayasa (2010), and Ramlan (2001) have not included this word in their Indonesian syntax.

Alwi (2003) placed the conjunction as a verb besides preposition, interjection, article, and particles. In line with this writing, Kridalaksana (1985) said that conjunction is the category that functions to widen the other units in hypotactic construction. Further, Widjono (2005) said that conjunctions act to connect parts of a sentence or from one sentence to other sentences in one discourse. The conjunction is grouped according to conjunction inter-clause and sentence. Referring to conjunctions, Ramlan (2008) described only the conjunction that states the relation of meaning inter-clause with the other clauses in the wide sentence; according to this view, there are seventeen more relations and can be more. Alwi (2003) stated that the inter-sentence conjunction connects one sentence with another sentence. Therefore, this conjunction always starts the new sentence and the first letter uses a capital letter. This conjunction may introduce a contrast from the previous sentence, such as "even though/so," "although/so," "though/so," "even so/so," and "nevertheless/so." Or the conjunction may state a continuation of a situation or something that happened in the previous sentence, such as, "then."

Other conjunctions stated that there is a case or other situation that has been stated before; examples are "after that," "then," "further," "next," "besides that," "moreover," and "apart from that." "Otherwise" refers to the opposite of what had been stated before. "Actually" indicates the real fact, and "but" shows contrast with the previous statement. "So" states the consequence. "Because of" states a cause. And "before" states that the incident precedes the case stated before. According to Standard Language of Indonesian (Alwi, 2003), the inter-sentence conjunction connects two main clauses. Because both sentences are separated, the subject in the second sentence is still used although the subject is the same as in the previous sentence. In nonstandard language, the subject omission is often done, but in the standard language, it is not done to start a sentence. 
Sriyono, Suhandano, and Poedjosoedarmo (2017) observed conjunctions in translation. According to these authors, the conditional conjunction in legal texts has its own characteristics. As a grammatical word, it differs from content words, for which translating the conditional conjunction leads to different techniques in translating the conditional conjunction. Most translation techniques applied single and double techniques, indicating that translating the conditional conjunction requires special thoughtfulness to gain equivalence both grammatically and semantically in the source text and target text (ST and the TT). Therefore, this study is necessary both in determining the language system in legal documents and in comprehending the legal effect in the TT as the consequence of translating the conditional conjunction. The aim in what follows is to describe (1) the function of adapun in Indonesian, (2) the meaning of adapun in Indonesian, (3) the appropriate sentence structure for using adapun.

\section{Literature Review}

Arifin (2015) stated that the conjunction is a means of fastening elements of discourse. The conjunction is easily recognized because it becomes a formal mentor. Types of conjunctions include the adversative conjunction (still, but), causal conjunction (because, since), correlative conjunction (moreover, so that), subordinative conjunction (if), and temporal conjunction (before that, after that, then). And there are those that can be used as inter-sentence or inter-unity conjunctions: so that, because of that, after that, so, and however. Further, it is stated that the conjunction is one means of connection of form or cohesion in discourse besides grammatical cohesion means, however that is a reference (endophora, exophore), substitution, and (eliptics).

Muslims and Nazarudin (2017) observed several conjunctions in their article, "Interclausal and Intersentential Conjunctions in Formal Written Indonesian." They mentioned that inter-clausal conjunctions - those that connect a clause with another clauseare usually distinguished from inter-sentential conjunctions - those that connect a sentence with another sentence. Examination of four Indonesian conjunctions of contrast - tetapi, namun, sedangkan, and padahal — on a corpus of written formal Indonesian shows that the four conjunctions are used both as inter-clausal and as inter-sentential conjunctions. In addition, their uses as inter-clausal conjunctions are more frequent than their uses as intersentential conjunctions. Indonesian grammars based on the language used by Indonesian 
speakers should take this fact and other intricacies of conjunctions uncovered from a corpus into consideration.

Research on intercellular conjunctions has been done by Mastini (2017) under the title "Antarctic Conjunction in the Balinese Language." What Mastini highlighted is meant intercostal conjunctions in the Balinese language. The results are that there are many forms of intercostal conjunctions in the Balinese language, among them sakewala (but), buina (again), sea (next), sajaba ento (other than that), yadiastun asapunika (though that is why) sekonden ento (before it), ento awinan (therefore), linen ento (other than that), suud keto (after that), and duaning asapunika (thus). Among other meanings, intercellular conjunctions in the Balinese language (1) state the continuation of the events or circumstances of the previous sentence, (2) state a contradiction with the previous state, (3) state any other event or circumstance beyond what has been previously stated, (4) declare the existence of exclusiveness and inclusiveness, (5) declare a contradiction of logical consequences to those stated in the preceding sentence, (6) state the consequences or things that themselves arise from another event, and (7) state the preceding statement as a reason for the event occurrence (Solikhah, 2017).

The conjunctions research has been done by Qomariyah, Sinaga, and Charlina (2017) under the title "Use of Conjunctions in the Kompas Newspaper." They found that (1) conjunctions used in the Kompas newspaper are subordinate, coordinative, correlative, intercostal, and interparagraph conjunctions; (2) the percentage of accurate use of conjunctions in the Kompas newspaper is $88.6 \%$ (meaning that the use of conjunctions in the Kompas newspaper is good); and (3) there are 18 meanings of conjunctions contained in headlines: addition, obedience, election, resistance, more, time, comparison, cause, result, requirement, hope/purpose, lighting, contents, usability, sample markers, and equate.

Similar research about the use of conjunctions has been done by Rira and Ardi (2013) under the title "The Conjunctions Used in Opinion Columns of Singgalang Newspaper." From the data obtained, 102 conjunctions are divided into coordinated, subordinative, and correlative conjunctions. The data analysis found that the coordinate conjunction is most often used (50.98\% of users), followed by the subordinate conjunction (31.37\%) and the correlative conjunction (17.64\%).

Nugraha, Ngalim, and Nasucha (2015) also examined "The Use of Conjunctions in the Language of Writing and Lisan by Five Elementary Schoolers of Baku Pandeyan Elementary School 01." They found that the oral Indonesian conjunction in the data consisted of subordinate conjunctions (182), coordinates (64), and inter-sentences (3). In Indonesian 
writing, there were 104 subordinate conjunctions and 49 coordinative conjunctions. The conjunction that is most often used by students is "and." Conjunction errors are common in usage for "and," "however," and "then." The study also revealed that the characteristics of subordinate conjunctions are (1) linking two equally important points; (2) connecting the same words or phrases, and (3) combining forms within compound sentences. The characteristics of coordinated conjunctions are (1) connecting two or more sentences with the same syntactic level, (2) forming a subordinate clause, and (3) joining phrases in complex sentences. The characteristics of inter-clause conjunctions are to connect one sentence with another sentence and to combine two sentences.

Sukarto (2017) wrote an article titled "Konjungsi Bahasa Indonesia: Suatu Tinjauan." Data analysis focused on samples of coordinate and subordinate conjunctions. The result showed that in Politika and Ranah there is the coordinate conjunctions usage "and," "on," and "but," and the subordinate conjunctions include "since," "if," "for," "order," "though," "cause," "because," and "until."

Concerning the use of conjunctions, Ningsih (2013) wrote a paper titled "Analysis of Misuse of Liaison in Students' Argumentation of Class X SMAN 3 Bintan Lesson Year 2012/2013," finding 59 errors of the liaison in the student arguments-19 misuses of connecting words, 36 misuses of the connecting word "and," three misuses of the connecting word "for," and two misuses of the connecting word "or."

Related to the conjunction in discourse, Hafish (2015) examined grammatical cohesion in a study titled "Anarchistic Cohesion in Discourse Panditfootball.com Period of May-June 2015." The study revealed four types of grammatical cohesion in the discourse of Panditfootball.com: references, substitutions, eliptions, and conjunctions. The use of grammatical cohesion devices is dominated by references, i.e., $47 \%$ with a total of 89 findings. The results showed that on the discourse Panditfootball.com more often use the type of grammatical reference cohesion.

Azis (2015) also examined the conjunctions associated with coherence in an article titled "Koherensi Paragraf dalam Skripsi Mahasiswa Prodi Pendidikan Bahasa dan Sastra Indonesia." The study found that there were 272 coherent paragraphs and 34 incoherent paragraphs. Findings were theses, results shown that there were five coherence markers found in the samples. These were repetition, substitution, pronoun, conjunction, and causal relation. It also was found that the coherent paragraphs consisted of explicit coherence (213 data) and implicit coherence (59 data). The explicit coherences were developed with the five coherence markers, and the repetition was the most dominant markers in use. By comparing the number 
of coherent with incoherent paragraphs, the coherence of students' writing in the introduction chapter was categorized as very good. Hikmah (2017) in her research title "An Analysis of Syntactical Errors Made by Eleventh Grade Student of Madrasah Aliyah Negeri” showed that there are five types of syntactical error and two causes of syntactical errors. The types of the syntactical errors are (1) omission (32.46\%), (2) mis-formation (22.72\%), (3) mis-selection (22, 41\%), (4) addition (17\%), and (5) mis-ordering (5.41\%). The causes of the students' syntactical errors are (1) intralingual and developmental (53.67\%) and (2) interlingual $(46.33 \%)$. Finally, the results imply that both teachers and students must see errors as the key to understanding and solve the syntactical errors in English writing lessons.

Abdullahi and Singh (2017) wrote about issues related to conjunctions under the title "Structure Shifts of Conjunctive Relations in the Translation of Animal Farm from English into Hausa." The study found that there are seven forms of structural shifts in the translation of conjunctive relations from English into Hausa. The study also revealed that all categories of conjunctive relations, i.e., additives, adversatives, causal, and temporal, were shifted in the translation, but their shifts differed between one classes of conjunction to another.

\section{Method}

We use a qualitative method with descriptive data, based on the empirical facts or phenomena that are relevant to the lives of the users. Thus the results are in the form of detailed and deep descriptions of language (Sudaryanto, 1993). The qualitative method is used to show the result got in the research is the description adapun. Sudaryanto's opinion is in line with that of Djajasudarma (2010) that the use of a qualitative method has the aim of making systematic and accurate descriptions about the data and their features, and the relations of the phenomenon observed.

Data collection is done by note taking (library research) - gathering research data from the written language, then recording the data on cards, followed by analysis. Before analysis, the collected data are selected and classified as needed. In the language its self so that, the theory used is structuralism de Sausure that every language element has relation one another and form the whole united (Djajasudarma, 2016). The technique of distributional study used is the release technique, to see the possibilities for the adapun feature. In addition, Bloomfield's theory of structuralism is used; this sees the language from the structural side intrinsically and neglects the extrinsic aspects of Indonesian (Ramlan, 2001). 
In the observation of the phenomena, including syntax and semantics, the conjunction is observed from the adapun position. From the semantic side, the meaning of adapun is observed with the basic sentence before containing adapun and that means adapun, observed the relation of the meaning of both sentences that are related with the word adapun.

The data sources derive from Indonesian print media: Kompas, Repu $\neg$ blika, Media Indonesia, and Tempo, Pikiran Rakyat. In addition, legal sources are used: a work by Sudaryanto titled "Lingual Data in Performance of Language Research Linguistically" and a work by Sudaryanto with titled "Descriptive Strategies of Archipelago Languages. Some paper notes in public lecture in FIB Padjajaran University, Jatinangor, April 2, 2015.”

\section{Results and Discussion}

The Function of Adapun/as forBased on its function, adapun is used as a conjunction among clauses, among sentences, and among paragraphs. The function of adapun has a close relation with the position of the conjunction. At the beginning of the paragraph, adapun functions as an inter-paragraph conjunction; at the beginning of a sentence, it functions as an inter-sentence conjunction; and within the sentence, it functions as an inter-clause conjunction.

\section{Inter-paragraph Conjunction}

When it is in the position at the beginning of paragraph, adapun functions as a conjunction and can be recognized from this position, namely jutted into (in writing). This is seen in the following examples.

(1) Adapun the mention of hadith with khabar; namely something that is spoken and relocated from someone to the others connected with the word tahdîts that means history, ikhbâr (to inform, let someone know). Allâh SWT also uses the word hadîts in this understanding.

(2) Adapun hadith according to experts of hadith is nearly the same as '(murodif) with sunnah, in which both have the meaning that everything is from the prophet, both appointed apostle or before that.

(3) Adapun determination guidelines of age based on the condition of horn and ring and the like: 1 . If it will be horn it seems to be a bit poky and hard when it is grabbed, the age is about 1 month.

(4) Adapun searching in Google shows the same result and most contents are also the same, bored with something like that and I think our knowledge will not improve if we 
only see and read the same writing, we must find the other sources and improve our knowledge.

(5) Adapun the humanistic culture at last shows the wisdom of the culture itself.

In examples 1-5 adapun functions as an inter-paragraph conjunction that connects the paragraph that means adapun with the previous paragraph.

Inter-sentence Conjunction

At the beginning of the sentence, adapun functions as an inter-sentence conjunction, and adapun as an inter-paragraph conjunction can be recognized from its position at the beginning of the paragraph. Inter-sentence use, in general, is found in writing. Adapun is generally followed by a comma, but as an inter-sentence conjunction, the comma is not found uniformly. The following examples show adapun as an inter-sentence conjunction:

(6) In Islam, the word buys and sell derived from the Arabic language "al bai' $u$ " the form of mufrot from the word "al buyuu" that means the exchange of goods. Adapun etymologically means "the exchange of something to something else." The other word dai albai'uhas the same meaning with the word asy-syira,al-mubadah, al-ijarah, namely the exchange of goods.

(7) Every word that can be grouped with the other words based on the general meaning is said a synonymous word. The word means the same meaning (denotation), but if different with its ordinary meaning and has a different value of taste (connotation). Ask for the meaning of denotation general feature literally or natural. The meaning of connotation contains emotion or the consideration of feeling that has the linkage with the heart situation.

(8) The items are the pictures of psychology test and the example of these items pictures psychological test are 5 kinds of items namely the series pictures and pictures identification.

(9) Adapun stranded characters on the chest, have not lined to form words then never you ask, when will I expose it.

(10) Adapun thousands of loneliness that you expect now becomes one, equal with the loneliness of the night, stand still.

In examples 6-10 adapun connects a sentence that contains adapun with the previous sentence.

Inter-clause Conjunction

In the middle of a sentence, adapun functions as an inter-clause conjunction, but there are only two examples from the data. This tells us that adapun tends to be an inter- 
sentence or inter-paragraph conjunction rather than an inter-clause conjunction. As an interclause conjunction, adapun begins with a comma. Two examples follow:

(11) Referring to Arabic Classics to pre-Islam Arabic Literature; Arabic Literature. This can only be said as the middle age Islam prose language, adapun the modern Arabic language refers to the use of formal language today, this variant is derivative of Arabic classics.

(12) Matching diversity of letter ' $g$ ' or 'ng' generally because of the factor of language of the users society themselves in Egypt area that generally use $>$ >phoneme equivalent /g/, whereas most used $\langle\dot{\varepsilon}\rangle$ and $\langle$ Sin Levant area (Lebanon, Syria, Jordan, Israel, Palestine and Cyprus) and Iraq, adapun $\langle\vec{\theta}$ for society in the area Arabian peninsula.

The Meaning of Adapun

Adapun is analyzed based on the connection of the sentence that contains adapun with the previous sentence.

Adding Information or Explaining the Previous Sentence

Some uses of adapun add information or explain the previous sentence. The position of the sentence that contains adapun indicates that it explains the previous sentence. There is a close connection between sentences. Examples follow.

(13) Among MS, the aspect of tone pattern is more popular and it is called lentong in MS, tone pattern aspect is more popular and it is called lentong (accent or dialect). Adapun the other features can be seen from some vocabularies that have limited numbers.

The sentence that contains adapun (exposing the feature of another vocabulary) explains the previous sentence, i.e., explains aspects of tone or lentong.

(14) The existence of TPS is regarded as the cause of the market condition that will be rebuilt. After burning on 2007 became not conducive. Adapun the traders chose to stay because they refused to pay for the new stall that is regarded as too expensive.

In example 14, adapun connects the previous sentence, that is the existence of TPS, with the sentence that contains the word adapun, namely the traders' condition that chose to stay.

(15) The six strategies are (1) the release from time stream, from transition place. And from the transition of the social layer (2) the release of three kinds of languages, (3) valid and reliable material retrieval (4) the distinction of two plains of language usage, (5) the understanding of differences. Adapun the strategies that seem to be strategic namely "valid and reliable material retrieval" is needed that the data must be applied. 
In example 15, adapun connects the previous sentence, that is, six strategies, and the sentence that contains adapun that explains the third strategy, namely taking over valid and reliable materials.

(16) Every word can be grouped with the other word based on the general meaning that is called the synonymous word. The words that mean the same center (denotation), but different in taste value (connotation). Adapun denotative meaning is general, literal, and neutral. The connotative meaning contains emotion or taste scale that connects with mood.

In example 16, adapun connects with the previous sentence, namely, denotative meaning that is different in taste value (connotation). Meanwhile, the sentence that contains adapun explains the meaning of denotation.

(17) The psychological test can be in the form of a picture. Adapun this picture test (spatial/room) has 5 kinds of picture series and picture identification.

In example 17, adapun connects the previous sentence, namely in the form of pictures. Meanwhile, the sentence that contains adapun explains the kinds of picture tests.

Usher in the Parsing

One of the functions of adapun is to usher the next sentence for parsing. But the data contain only two examples of adapun that have the meaning of ushering the parsing.

(18) Arsul explains, from ten the candidates of leaders, there are three doubtful names. In line with the first document given by selection committees of leaders candidates of KPK Adapun, the tenth leaders candidates are Saut Situmorang, Surya Chandra, Alexander Marwata, Basariah Panjaitan, Agus Rahardjo, Johan Budi Sapto Prabowo, Sujanarko, Laode Muhammad Syarif, Busyro Muqoodas and Robby Arya Brata.

The function of adapun in example 18 is the usher of the previous parsing. As stated in the previous sentence, there are 10 leader candidates of KPK, and the word adapun parses these 10 names. The same thing can be found in the following.

(19) From the research 5 lexicon are got for mentioning five fish cork in Bincau village society. Adapun the mentioned names are the naming of Bincau Village Society, Martapura District, Banjar Regency.

The sentence before handing over there are five lexicomes to call fish cork. The five cork fish laxis conveyed to the sentence containing hichever.

\section{Stating Something Different but in One Domain}

Some uses of adapun state something different from what was stated before, but in one domain. Between the previous sentence and the sentence that contains adapun, the relation is not so close. The position that contains apapun and the previous sentence is the 
same from the side of the main sentence and the explanatory sentence. Adapun has the function of stating something different but in one domain. This use can be seen in the following sentence.

(20) For essay and thesis the term of supervising a team with the position of Supervisor I and supervisor. Adapun for dissertation the term of promotor, co-promotor, and member is used.

In example 20, adapun connects something different although it still has a relation (one domain), namely the essay and thesis compared with the dissertation. The essay, thesis, and dissertation are kinds of scientific writing for the levels of S-1, S-2, and S-3.

(21) In that activity, President Jokowi all at once submits awards to the winners of tree planting competition 2014, Wana Sustainable Competition 2015, Embedding a Sign of Honor Satya Badge and the launch of the latest postage puspa and wildlife. Postage stamp series puspa with the suweg picture. Adapun wildlife series pictured Nias parrot.

In example 21, adapun connects something different, though it still has a relation (one domain), namely the postage stamp puspa series and the wildlife series. Both stamps were launched by President Jokowi.

(22) Hoed explains that study about today's culture has become the attention of development of semiotic theory both structurist and pragmatic. Adapun hermeneutic approach is used as an interpretive model toward the meaning of proposition discussed in this book.

In example 22, adapun connects something different though it still has a relation (one domain), namely the development of a semiotic theory that relates with adapun. After adapun the hermeneutic approach is discussed.

(23) The re-word meant has the clear basic form, and the basic form meant is directly spoken without addition or deduction of the element, and forms the unity of the word. Adapun the other re-word, not whole basic form is repeated but there is a change in sound. The word like that includes support data. The re-word mentioned, its explanation refers to the explanation about the full re-word functions as the basic word.

In example 23, adapun connects something different, though it still has a relation (one domain), namely a re-word that contains adapun that discusses the other re-word.

(24) On the sentential level, what is discussed is the topic problem and speech focus found in the sentence and cohesion and coherence which is of discretionary nature on the components of discourse in the certain sentences. Adapun suprasentential level which object is far above sentence, namely some monologue that is a part of dialogue or polilogue or conversation or self-sufficiency. 
In example 24, adapun connects something different, though it still has a relation, namely the sentential level, and the sentence that contains adapun discusses suprasentential.

\section{Declaring Information A Bit Far}

The last function of adapun is to act as an usher for information that is a bit far away. Information is delivered to the sentence that contains adapun and the previous sentence that is far before that.

(25) As president, Jokowi emphasizes that he holds on three ideologies, namely independent, self-sufficiency and has personality. Adapun/as for the event was attended by chairman of NasDem party Surya Paloh; chairman of Golkar party National Conference version, agung Laksono, a number of Cabinet work, and the ambassadors of friendly countries. (D)

(26) But the process in Court of law will run smoothly if there will be more parties that wish Setya Novanto stepped down. Adapun the process of criminal needs further review, moreover if wanted to be snared by the Anti-Corruption Laws.

(27) The strategy in question is used to handle the things that want to be described. The strategy in question is beneficial to make the steps of handling the description effective and efficient Adapun that is meant by "description method") is the way to handle the described object.

(28) The proposition is the culture data in the form of text speech. Preposition has the truth element that can be provable because it had gone through the deep thinking process based on the fact in the real world. The example is in preposition aja dumeh/ not just because becomes the formulation of the thought of culture about "self-control." Adapun the art element in Javanese that is meant by this book is the speech that is served with the art language (beautiful) namely basa rinengga.

(29) Thesaurus is a kind of dictionary that specializes in various meanings and forms of a set of lingual unity that have inter-relations with one another, both synonyms and antonyms. Adapun the story about the life of language that is described that can embrace quality and quantity aspects of speakers, the place of the language and its spread and the typical type, even the various observers and researchers and their works, and the developers of language institution etc.

\section{Sentence Structure that Contains Adapun}

The collected data show that in great measure the predicate that contains adapun is/adalah is the word adalah. So it can be said that adapun functions to state a definition. The sentence that contains adapun and has a predicate can be seen in the following sentence. 
(30) In the level of sentential the topics discussed are speech focus in the sentence and cohesion and coherence and it is a matter of discourse seen in discourse component in the certain sentences. Adapun the level of suprasentential is the level tataran suprasentensial adalah tataran yang objeknya jauh berada on the sentence, namely, various part of monologue or polylogue or conversation or self-sufficiency.

(31) The strategy meant is useful to handle the things that want to be described. The strategy is useful to make the steps to description handling become effective and efficient. Adapun description method is the way to handle the described object.

(32) The definition of culture according to this book is the whole process of thought and human effort understood and internalized and become joint property through a learning process to overcome the limitation of people to survive and facilitate his existence. Adapun culture data in this book adalah the source of information that has not fully given the understanding of information source and give an understanding about culture.

(33) Adapun the suggestion that can be conveyed are as follows: 1) The usage type composite Paruntuk Kana in the composite in that analyzed Makasar type Paruntuk Kana dalam ungkapan Makassar language that writer that is analyzed. Further, it is expected that writer can analyze. The discussion is reviewed by the other type in Makasar language: The other type of further analysis still limited, especially kelong andaru.

(34) The proposition is culture data in the form of text speech. Proposition has the truth element that can be proven because the deep-thinking process has been gone through in the real world.

Besides with is/adalah as a predicate, there are many words is/adapun means ialah and means/berarti. This case can be seen from the following examples.

(35) The other element apart from composite is identified with Y. Adapun sub-types from subordinative is.

(36) Note: The sign of curly bracket \{\} means constituent (or special formative mentioning "formatif") that is found in it can be chosen one of them; sign of square bracket [ ] that couple when the constituent or the first formative on the sign [ ] if the first is chosen then the first formative on the sign [ ] the second must be chosen; and if the constituent or the second formative on the sign [ ] the first is chosen then the constituent or the second formative on the sign [ ] the second must be chosen and so on. Adapun the sign vertical three dots mean that the list can be added with formative or new constituent no matter what the sums are, in a condition that is suitable and relevant. 
(37) Thesaurus is a kind of dictionary that specializes in various meanings and forms of lingual unit device that have inter-relations with one another, both the connection of synonym and antonym. Adapun the story about the life of language that is described involves quality and quantity aspect of the speakers, the place of the presence of the language, its spread, the typical type, and even the observers and the researchers along with their works, the language institute of the developer, etc.

(38) Concepts of lingual expression and (6) starting and ending the steps of research. Adapun three methods spoken are identified/based on the step of handling of its object namely method of providing data, 2 data analysis methods, and method of serving the result of data analysis.

(39) The rupiah exchange rate against the US dollar seems not able to withstand the strength of dollar yesterday afternoon. This morning rupiah weakens Rp 2,5 or 0,18 percent in the level Rp 11.721 per USD. Adapun the daily movement of rupiah, is in the level Rp11.715Rp11.725 per USD. This attenuation is caused by the impacts of other Asian currencies.

In general, the sentence that contains adapun is a simple sentence usually in the form of a phrase (long) with the pattern S-P-O. Examples can be seen below.

(40) Adapun the Head of the Nation Intelligence Agency Marciano Norman makes sure the identity in ISIS video.

(41) Adapun the pattern of speech in sell and buy interaction in Sindang market happened in all level of communication, namely: society, group, and individual. In the level of society, there is the pattern in the form of concepts in time of BJ.

(42) Adapun object studied in the advertisement are the words found in ads.

(43) Adapun the direct and indirect interview technique done if the informant experiences difficulties in giving the answer; for instance, by using relevant pictures and props.

(44) Adapun the services offered, one of them arranging and attending the meeting with the stakeholders and congress members and executives, including the ministry of foreign affairs.

Adapun that is followed by information (not $\mathrm{S}$ ). But there is only one example:

(45) Adapun to support the implementation the broadcast of digital television, says Ismail. The ministry has given some suggestion in the revision of Broadcasting Laws.

Besides this, in only one example, adapun is followed by a subordinate clause. 
(46) Adapun when separated and alone outside the text, letters characters used may not be different with the one that is used the text of the description of exposure to the idea of the researchers.

In general, adapun is used in a variety of ways. Meanwhile, adapun can be redone with the meaningful conjungtordapat disulih dengan konjugtor yang semakna, such as temporarily and meanwhile.

\section{Conclusion}

From the result and discussion, it can be concluded that:

(1) Based on its function, adapun functions as an inter-clause, inter-sentence, and inter-paragraph conjunction. The function of adapun has a close relation with the position of the conjunction. When adapun is positioned at the beginning of the paragraph, it is intended (in writing) as an inter-paragraph conjunction. When it is positioned at the beginning of the sentence, it functions as an inter-sentence conjunction. And when it appears in the sentence it functions as an inter-clause conjunction. In writing, adapun functioning as a conjunction between sentences is different from the conjunction between sentences, in general. In general, as a conjunction adapun is followed by a comma, but after adapun, as a conjunction between sentences, a comma is not found uniformly. Adapun positioned in the middle of the sentence functions as a conjunction between clauses (however, there are only two examples from the data). This signifies that adapun tends to be a conjunction between sentences or paragraphs rather than between clauses. As a conjunction between clauses, adapun can be identified from its position, and it is begun with a comma.

(2) In terms of meaning, adapun is analyzed based on the linkage of the sentence with the previous sentence. Some uses of adapun have the function of adding information or clarifying the previous sentence. The position of the sentence which contain as for is the explanatory sentence from the previous sentence. Besides between the sentence that contains wherever with the previous sentence has the close relation. The other function is to introduce the next sentence, and its nature is to parse. Some of the "wherever" function to state something different from what was stated before, but it remains in one domain. Between the previous language with the sentence that contains "as for," the relation is not so close. The position of the sentence that contains "wherever" and the previous sentence is the same from the side of the main sentence and the explanatory sentence. As for that has the function to state something different, but in one domain found in many examples if compared with the 
function the other as for. The last function of "as for" is as the introduction of information that is rather far away.

(3) From the available data, it can be said that in large measure the predicate that contains "as for" is the word "is." So "as for" functions to state a definition. In general, the sentence pattern that contains "as for" is a single sentence with the subject in the form of a phrase (long) with the pattern S-P-O/Pel.

\section{REFERENCES}

1. Abdullahi, M. S. \& Singh K. K. A. G. (2017). Structure shifts of conjunctive relations in the translation of animal farm from english into hausa. Pertanika Journal of Social Science \& Humanity, 25(2), 861-876.

2. Alwi, H. (2003). Tata bahasa baku Bahasa Indonesia [Indonesian language standard grammar]. Jakarta: Balai Pustaka.

3. Arifin, Z. E. (2015). Wacana: Transaksional dan interaksional dalam Bahasa Indonesia [Discourse: transactional and interactional in Indonesian]. Tangerang: Pustaka Mandiri.

4. Azis, A. W. (2015). Kohesi paragraf dalam skripsi mahasiswa prodi pendidikan Bahasa dan Sastra Indonesia [Paragraph cohesion in student thesis Indonesian Language and Literature education study program]. Dialektika: Jurnal Pendidikan Bahasa, Sastra, dan Matematika, 1(2), 173-187.

5. Chaer, A. (2009). Sintaksis Bahasa Indonesia: Pendekatan proses [Indonesian syntax: Process approach]. Jakarta: Rineka Cipta.

6. Djajasudarma, F. T. (2010). Metode linguistik: Ancangan metode penelitian dan kajian [Linguistic methods: Threats of research and study methods]. Bandung: Refika Aditama.

7. Djajasudarma, F. T. (2016). Penalaran deduktif-induktif dalam wacana Bahasa Indonesia: Modul mata kuliah analisis wacana [Deductive-inductive reasoning in Indonesian discourse: Module discourse analysis course]. Jatinangor: Fakultas Ilmu Budaya.

8. Hafish, F. (2015). Kohesi gramatikal antarklimat dalam wacana panditfootball.com periode Mei-Juni 2015 [Grammatical cohesion between clusters in the panditfootball.com discourse for the period May-June 2015] (Unpublished bachelor's thesis). Department of Indonesian Language and Literature, Yogyakarta State University, Indonesia.

9. Hikmah, H. (2017). An analysis of syntactical errors made by eleventh grade students of madrasah aliyah negeri. Ling Tera, 4(2), 177-187. 
10. Kridalaksana, H. (1985). Tata bahasa deskriptif Bahasa Indonesia: Sintaksis [Descriptive grammar in Indonesian: Syntax]. Jakarta: Pusat Pembinaan dan Pengembangan Bahasa.

11. Mastini, G. N. (2017). Konjungsi antarkalimat dalam Bahasa Bali [Intersentential conjunction in Balinese Language]. Proceedings of Seminar Nasional Bahada dan Budaya 2017. Denpasar: Fakultas Dharma Acarya.

12. Ministry of Education. (2005). Kamus besar Bahasa Indonesia [Indonesia dictionary]. Jakarta: Balai Pustaka.

13. Muslim, U. M. \& Nazarudin. (2017). Interclausal and intersentential conjunctions in formal written Indonesian. Retrieved from www.academia.edu/.../INTERCLAUSAL_AND_INTERSENTENTI

14. Ningsih, R. D. (2013). Analisis kesalahan penggunaan kata penghubung dalam karangan argumentasi siswa kelas X SMA Negeri 3 Bintan tahun pelajaran 2012/2013 [Analysis of misuse of conjunctions in essay arguments of class X Bintan 3 SMA SMA 2012/2013 academic year] (Unpublished bachelor's thesis). Department of Indonesian Language and Literature,Raja Ali Haji Maritime University, Tanjungpinang, Indonesia.

15. Nugraha, O. A., Ngalim, A. \& Nasucha, Y. (2015). Penggunaan konjungsi dalam bahasa tulis dan lisan oleh siswa kelas lima sekolah Dasar Baki, Pandeyan, Sukoharjo [Use of conjunctions in written and oral language by fifth grade students at Baki Elementary School, Pandeyan, Sukoharjo]. Jurnal Penelitian Humaniora, 16(2), 43 50.

16. Putrayasa, I. B. (2010). Kajian morfologi (bentuk derivasional dan infleksional) [Morphological studies (derivational and inflectional forms)]. Bandung: PT Refika Aditama.

17. Qomariyah, S., Sinaga, M., \& Charlina. (2017). Use of conjunctions in the kompas newspaper. Retrieved from https://media.neliti.com/media/publications/206515penggunaan-konjungsi-dalam-surat-kabar-k.pdf

18. Ramlan, M. (2001). Ilmu Bahasa Indonesia: Sintaksis [Indonesian language: Syntax]. Yogyakarta: CV Karyono.

19. Ramlan, M. (2008). Kalimat, konjungsi, dan preposisi Bahasa Indonesia dalam penulisan karangan ilmiah [Sentences, conjunctions, and prepositions of Indonesian in scientific writing]. Yogyakarta: Universitas Sanata Dharma.

20. Rira, F. \& Ardi, H. (2013). The conjunctions used in opinion columns of singgalang newspaper. English Language and Literature E-Journal, 2(1), 106-111.

21. Solikhah, I. (2017). Corrections on grammar, sentence variety and developing detail to qualify academic essay of Indonesian learners. Dinamika Ilmu, 17(1), 115-129.

22. Sriyono, Suhandano, \& Poedjosoedarmo, S. (2017). Translating english conditional conjunction legal texts into Indonesian. International Journal of English Language and Translation Studies, 5(4), 22-31.

23. Sudaryanto. (1993). Metode dan aneka teknik analisis bahasa: Pengantar penelitian wahana kebudayaan secara linguistis [Methods and various language analysis 
techniques: Introduction to linguistic research on cultural vehicles]. Yogyakarta: Duta Wacana University Press.

24. Sukarto, K. A. (2017). Konjungsi Bahasa Indonesia: Suatu tinjauan [Indonesian conjunction: A review]. Jurnal Pujangga, 3(1), 99-112.

25. Widjono, H. (2005). Bahasa Indonesia: Mata kuliah pengembangan kepribadian di perguruan tinggi [Indonesian: A personality development course in college]. Jakarta: Grasindo.

\section{SOBRE OS AUTORES:}

\section{Umi Kulsum}

Graduate student of Faculty of Humanities, Padjadjaran University, Sumedang, West Java, Indonesia. E-mail: umikulsum_1973@yahoo.co.id

(iD http://orcid.org/0000-0002-1795-165X

\section{Cece Sobarna}

Professor of Linguistics and lecturer in Literature Study Program, Faculty of Arts, Padjadjaran University, Sumedang, West Java, Indonesia. E-mail: cece@unpad.ac.id

iD http://orcid.org/0000-0003-3513-4239

\section{Tajudin Nur}

Professor of culture science and lecturer in Linguistics Department, Faculty of Humanities, Padjadjaran University, Sumedang, West Java, Indonesia. E-mail: tajudin.nur@unpad.ac.id

(iD http://orcid.org/0000-0003-4054-3467

\section{Wagiati}

Chief of Linguistics Program, Faculty of Culture Science, Padjadjaran University, Sumedang, West Java, Indonesia. E-mail: wagiati@unpad.ac.id

(iD) http://orcid.org/0000-0003-0418-4479 